Terakreditasi Sinta 3 | Volume 4 | Nomor 4 | Tahun 2021 | Halaman 425-440

P-ISSN 2615-725X | E-ISSN 2615-8655

http://diglosiaunmul.com/index.php/diglosia/article/view/280

\title{
Fonologi Bahasa Minangkabau Isolek Sikucur
}

\author{
Phonology in Minangkabau Language of Sikucur Isolect
}

\author{
Nastiti Kharisma ${ }^{1, *}$, Nadra $^{2}$, dan Reniwati ${ }^{3}$ \\ ${ }^{1,2,3}$ Program Magister Linguistik, Universitas Andalas Padang \\ 1,* Email: nastitikharisma@gmail.com \\ ${ }^{2}$ Email: nadra@hum.unand.ac.id \\ ${ }^{3}$ Email: reniwati@hum.unand.ac.id
}

Received: 25 July 2021 Accepted: 2 October 2021 Published: 2 November 2021

\begin{abstract}
Minangkabau language is one of the regional languages in Indonesia. The purpose of this study was to determine the sounds, phonemes and their distributions in Minangkabau language of Sikucur isolect. The observation and interview methods were used to obtain data. During the interview, the results of the interview were recorded and phonetic transcription was made based on IPA chart. Furthermore, the method used to analyze the data was a phonetic articulator matching method. The data that had been collected was classified according to sound pairs that were phonetically similar. The results showed that there were 30 phonemes found. There were five vowels: / $\mathrm{l} / \mathrm{l} / \mathrm{e} / \mathrm{l} / \mathrm{l} / \mathrm{I} / \mathrm{l} /$, and $/ \mathrm{o} /$. Each vowel had an allophone, namely [i I], [e $\sim \varepsilon],[a \sim 1],[u \sim v]$, dan [o o]. There were seven diphthongs: /aw/, /ay/, /uy/, /ua/ with allophones [ua ue], /ia/

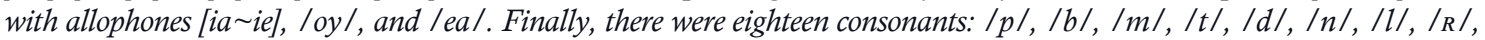
$/ s /,|c /|, j /, / \mathrm{h} /, \mid \mathrm{k} /, \mathrm{g} /, / \mathrm{g} /, / \mathrm{h} /, / \mathrm{w} /$, and $/ \mathrm{y} /$. The sound [?] was the realization of $/ \mathrm{k} /$ when it was at the end of the closing syllable. Furthermore, $[R]$ and $[r]$ were free variations and did not differentiate in meaning.
\end{abstract}

Keywords: sounds, phonemes, Minangkabau language, Sikucur isolect

Abstrak: Bahasa Minangkabau adalah salah satu bahasa daerah di Indonesia. Penuturnya terutama tersebar di beberapa daerah di Sumatera Barat. Setiap daerah mempunyai ciri khas, salah satunya dari segi fonologisnya. Salah satu perbedaan tersebut terdapat pada bahasa yang dituturkan di Nagari Sikucur. Penelitian ini bertujuan untuk mengetahui bunyi, fonem beserta distribusinya yang terdapat dalam bahasa Minangkabau isolek Sikucur. Metode untuk memperoleh data ialah metode cakap dan simak. Selama wawancara berlangsung, hasilnya direkam, dicatat, dan dibuat transkripsi fonetisnya berdasarkan IPA chart. Selanjutnya, metode analisis data adalah metode padan fonetis artikularoris. Data yang telah dikumpulkan dikelompokkan sesuai dengan pasangan bunyi yang memiliki kemiripan secara fonetis. Hasil penelitian menunjukkan ada 30 fonem. Terdapat lima fonem vokal: /i/, /e/. /a/, /u/, dan /o/ dengan alofonnya, yaitu $[\mathrm{i} \sim \mathrm{I}],[\mathrm{e} \sim \varepsilon],[\mathrm{a} \sim \Lambda],[\mathrm{u} \sim 0]$, dan $[\mathrm{o} \sim 0]$. Ada tujuh fonem diftong: /aw/, /ay/, /uy/, /ua/ dengan alofon [ua ue], /ia/ dengan alofon [ia ie], /oy/, dan /ea/. Terakhir, ada delapan belas fonem konsonan: /p/, /b/, /m/, /t/, /d/, /n/, /1/, /R/, /s/, /c/, /j/, /p/, /k/, /g/, /g/, /h/, /w/, dan /y/. Bunyi [?] merupakan realisasi dari /k/ apabila berada di silabel akhir tertutup. Selanjutnya, [R] dan [r] merupakan variasi bebas dan tidak membedakan makna.

Kata kunci: bunyi, fonem, bahasa Minangkabau, isolek Sikucur

To cite this article:

Kharisma, N., Nadra, N., \& Reniwati, R. (2021). Fonologi Bahasa Minangkabau Isolek Sikucur. Diglosia: Jurnal Kajian Bahasa, Sastra, dan Pengajarannya, 4(4), 425-440. https://doi.org/10.30872/diglosia.v4i4.280 


\section{A. PENDAHULUAN}

Indonesia merupakan negara yang memiliki beragam bahasa daerah. Oleh karena itu, masyarakat Indonesia merupakan masyarakat yang bilingual atau multilingual karena menggunakan dua atau lebih bahasa dalam kehidupan seharihari. Lia et al. (2018) menyatakan bahwa kemungkinan dalam kehidupan sehari-hari penggunaan bahasa Indonesia hanya untuk komunikasi tertentu saja seperi pada komunikasi yang bersifat formal. Sementara, untuk percakapan dalam kehidupan sehari-hari yang digunakan adalah bahasa daerah masing-masing. Hal ini juga berlaku untuk masyarakat yang menetap di daerah Sumatera Barat yang dalam kehidupan sehari-hari lebih banyak menggunakan bahasa Minangkabau.

Bahasa Minangkabau adalah salah satu bahasa daerah yang ada di Indonesia. Penuturnya terutama tersebar di beberapa daerah di Sumatera Barat. Meskipun penuturnya sama-sama menggunakan bahasa Minangkabau, namun di setiap daerah terdapat ciri khas tersendiri, salah satunya adalah dari segi fonologisnya. Salah satu perbedaan tersebut terdapat pada bahasa Minangkabau yang dituturkan di Nagari Sikucur Kecamatan V Koto Kampung Dalam Kabupaten Padang Pariaman. Bahasa Minangkabau isolek Sikucur (yang selanjutnya disingkat menjadi BMIS) ini juga memiliki kaidah yang bersistem. Sistem inilah yang diikuti oleh masyarakat di sana sehingga mereka bisa berkomunikasi dengan lancar. Salah satu ciri khas dalam BMIS adalah adanya penggunaan diftong yang berbeda dengan diftong yang digunakan pada bahasa Minangkabau umum. Seperti penggunaan diftong [ie] dalam kata [li.hie] bermakna 'leher' dan [ue] dalam kata [ku.hue] yang berarti 'batuk'. Kedua diftong ini tidak ditemukan dalam bahasa Minangkabau pada umumnya. Secara umum, menurut Ayub et al. (1993), bahasa Minangkabau mempunyai 7 diftong. Diftong-diftong tersebut ialah /ia/, /ua/, /ea/, /uy/, /oy/, /aw/, dan /ay/. Dalam BMIS, diftong /oy/ juga tidak ditemukan.

Selanjutnya, dalam BMIS juga ditemukan adanya penggunaan bunyi $[\Lambda]$, misalnya dalam kata [u.lı] yang bermakna 'ular'. Selain perbedaan yang diutarakan di atas, dalam BMIS juga ditemukan bunyi kontoid yang menarik perhatian, yakni adanya penggunaan bunyi glotal [?] yang berada pada silabel akhir, contohnya dalam kata [ka.Ruy?] yang artinya 'rambut ikal'. Selain itu, Nagari Sikucur termasuk salah satu daerah di Sumatera Barat yang menggunakan [R] uvular. Hal ini dapat dilihat dalam kata [sa.Riay] yang artinya adalah 'gigi taring'.

Selain ciri khas yang diutarakan di atas, alasan lain penelitian fonologi BMIS ini perlu dilakukan adalah karena sejauh pengetahuan peneliti, belum ada penelitian mengenai BMIS, terutama dalam bidang fonologi. Hal ini diharapkan mampu menambah perbendaharaan penelitian bahasa daerah yang ada di Sumatera Barat, khususnya pada bidang fonologi. Dengan demikian, BMIS ini nantinya dapat diteliti dan dikembangkan dari berbagai bidang linguistik lainnya.

Penelitian-penelitian mengenai fonologi bahasa daerah telah banyak dilakukan oleh beberapa peneliti sebelumnya. Seperti pada penelitian yang dilakukan oleh Rahman et al. (2019) yang melalukan penelitian mengenai bahasa Kerinci dengan judul "Variasi Bunyi Bahasa Kerinci Isolek Rawang". Tujuan dari penelitiannya adalah untuk mengetahui bunyi-bunyi, fonem-fonem, dan variasi bahasa yang terdapat dalam bahasa Kerinci isolek Rawang. Hasil penelitiannya adalah ditemukan enam fonem vokal, delapan belas fonem konsonan, dan sepuluh fonem diftong.

Selanjutnya, ada juga penelitian yang dilakukan oleh Krulikowska et al. (2020) yang meneliti bahasa yang digunakan di daerah Jambi dengan judul "Phonological 
Sketch of Malay Jambi Language of Sarolangun, Indonesia". Senada dengan penelitian yang dilakukan Rahman et al. (2019), penelitian Krulikowska et al. (2020) ini bertujuan untuk mengetahui bunyi dan fonem yang terdapat dalam bahasa Melayu di daerah Jambi. Dari hasil penelitiannya diperoleh bahwa ada sebanyak enam vokal dan dua puluh konsonan dalam bahasa Melayu isolek Sarolangun.

Selain dari penelitian fonologi bahasa daerah yang dijabarkan sebelumnya, ada juga beberapa penelitian fonologi bahasa Minangkabau yang telah dilakukan oleh beberapa peneliti terdahulu. Seperti penelitian yang dilakukan oleh Almos (2012) dalam penelitiannya yang berjudul "Fonologi Bahasa Minangkabau: Kajian Transformasi Generatif' yang menemukan adanya 5 vokal secara fonemik dalam bahasa Minangkabau. Vokal tersebut ialah /a/, /i/, /u/, /e/, dan /o/. Sementara,

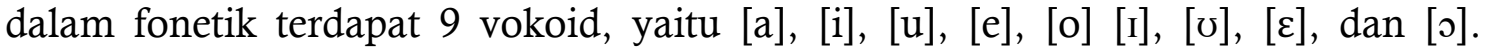
Selanjutnya, Almos (2012) menyatakan bahwa secara fonemis terdapat 18 konsonan, yaitu /p/, /b/, /t/, /d/, /c/, /j/, /k/, /g/, /r/, /1/, /s/, /h/, /m/, /n/, /g/, /ñ /, /w/, dan /y/. Sementara, secara fonetis ada 19 bunyi kontoid, yakni [p], [b], [t], [c], [j], [k], [g], [r], [1], [s], [h], [m], [n], [y], [ñ], [?], [w], dan [y].

Selain penelitian yang dilakukan oleh Almos (2012) di atas, penelitian lainnya mengenai bahasa Minangkabau ini dilakukan oleh Rahmadani et al. (2013) dengan judul "Perbedaan Fonetik Bahasa Minangkabau di Kenagarian Sinuruik dan Kenagarian Kajai Kecamatan Talamau Kabupaten Pasaman Barat". Dilihat dari judulnya sangat jelas bahwa tujuan penelitiannya adalah untuk melihat perbandingan penggunaan bahasa Minangkabau yang digunakan di dua daerah yang berbeda dalam satu kabupaten yang sama. Hasil penelitiannya menunjukkan bahwa ditemukannya 4 jenis perbedaan antara bahasa Minangkabau yang digunakan di Kenagarian Sinuruik dan Kenagarian Kajai. Perbedaan tersebut adalah (1) adanya 9 perbedaan vokal, (2) terdapat 12 perbedaan konsonan, (3) ditemukan 3 perbedaan diftong, dan (4) diperoleh 3 perbedaan campuran.

Selanjutnya, penelitian yang serupa juga dilakukan oleh Krulikowska et al. (2020) yang meneliti fonologi bahasa Melayu Jambi isolek Sarolangun. Walaupun bahasa yang diteliti berbeda, tetapi metode yang diterapkan untuk mengumpulkan dan menganalisis data mempunyai persamaan, yaitu menggunakan metode cakap dan simak sebagai metode pengumpulan data beserta metode padan fonetis artikulatoris yang digunakan sebagai metode untuk menganalisis data. Walaupun demikian, hasil penelitian yang dicapai berbeda karena adanya perbedaan lokasi dan bahasa yang dijadikan sebagai objek penelitian.

Dari pembahasan di atas, dapat dilihat bahwa ada beberapa penelitian yang berhubungan dengan fonologi bahasa daerah. Penelitian-penelitian tersebut memiliki persamaan dan perbedaan. Seperti halnya penelitian yang dilakukan oleh Almos (2012) dan Rahmadani et al. (2013) yang meneliti bahasa Minangkabau. Namun, Almos (2012) tidak hanya membahas fonologi bahasa Minangkabau saja karena kajiannya berupa kajian transformasi generatif. Selanjutnya, lokasi penelitian yang dilakukan oleh Rahmadani et al. (2013) juga berbeda dengan lokasi penelitian ini. Dengan demikian, dapat disimpulkan bahwa belum ada ditemukan penelitian mengenai fonologi BMIS. Selain itu, diharapkan juga pada kajian-kajian terdahulu ini dapat menjadi referensi dan acuan yang baik untuk membantu menganalisis data dalam penelitian ini. Hal ini yang menjadi alasan mendasar bagi penelitian fonologi BMIS sangat penting untuk dilakukan agar bisa menambah penelitian-penelitian fonologi bahasa daerah yang ada di Indonesia. 
Selanjutnya, penelitian ini merupakan penelitian fonologi yang bersifat sinkronis karena data yang diperoleh diambil dalam satu kurun waktu. Sebagaimana makna dari istilah sinkronis itu sendiri, menurut Kridalaksana (2013) adalah hal-hal yang bersangkutan dengan peristiwa yang terjadi dalam suatu waktu atau masa yang terbatas dan tidak melibatkan perkembangan sejarah atau berkenaan dengan pendekatan bahasa dengan melibatkan perkembangannya sepanjang waktu. Oleh sebab itu, penelitian ini bersifat sinkronis karena penelitiannya hanya dilakukan dalam satu waktu saja, yaitu bagaimana penggunaan bahasa di suatu daerah yang terjadi pada masa sekarang saja.

Untuk itu, penelitian ini dibatasi pada hal-hal yang berhubungan dengan kajian fonologi. Roach (2012) mendefinisikan fonologi sebagai sebuah kajian ilmu yang membedakan bunyi-bunyi pada sebuah bahasa, pola apa saja yang membentuknya, serta aturan yang digunakan. Berikutnya, O'Grady (2017) menambahkan bahwa fonologi merupakan unsur-unsur dan prinsip-prinsip yang menentukan pola bagaimana suara terbentuk di dalam sebuah bahasa. Jadi, dari definisi yang telah dikemukakan mengenai fonologi dapat diambil kesimpulan bahwa fonologi adalah sebuah ilmu yang mempelajari bunyi-bunyi yang terdapat di dalam bahasa manusia yang diucapkan melalui alat ucap manusia dan memiliki keteraturan yang ada di dalam bunyi tersebut.

Fonologi terdiri atas dua bagian, yakni fonetik dan fonemik. Fonetik secara umum, menurut Alwasilah (2011) adalah suatu kajian ilmiah tentang bunyi-bunyi suatu bahasa. Secara khusus, di dalam fonetik, hal-hal yang dikaji berupa komponenkomponen bunyi suatu bahasa secara rinci dari aspek fisik (pengujaran, penyampaian ujaran, dan penerimaan bunyi) dan dari aspek fungsional yaitu peran yang dimainkan oleh bunyi-bunyi ujaran pada suatu bahasa tertentu (fonologi). Dengan demikian, fonetik di dalam penelitian ini berhubungan dengan bunyi-bunyi yang dituturkan oleh masyarakat di Nagari Sikucur. Sementara, fonemik seperti yang diungkapkan oleh Chaer (2013) adalah bunyi yang dapat membedakan makna. Contohnya terdapat pada bunyi [t], [a], [r], [i] dan [d], [a], [r], [i]. Jika dilihat sepintas maka diketahui bahwa perbedaannya hanya terdapat pada bunyi yang pertama saja, yaitu pada bunyi [t] dan [d], sehingga dapat disimpulkan bahwa bunyi-bunyi tersebut adalah fonem yang berbeda dalam bahasa Indonesia, yaitu fonem $/ \mathrm{t} / \mathrm{dan} / \mathrm{d} /$. Selanjutnya, Muslich (2013) menyatakan cara yang dilakukan untuk mengetahui bahwa fonem tersebut bisa membedakan makna adalah dengan melakukan pembuktian secara empiris, maksudnya dengan membandingkan bentuk-bentuk linguistik bahasa yang diteliti.

Oleh sebab itu, di dalam penelitian ini dilakukan proses fonemisasi. Menurut Siminto (2013) fonemisasi adalah sebuah proses yang dilakukan untuk menemukan fonem yang terdapat di dalam suatu bahasa. Salah satu langkah yang bisa digunakan adalah dengan mencari pasangan minimal, yaitu bentuk-bentuk bahasa yang terkecil dan bermakna dalam sebuah bahasa yang secara ideal sama, kecuali ada satu bunyi yang tidak sama. Jadi, dengan menggunakan prosedur untuk mencari pasangan minimal maka didapat fonem-fonem beserta distribusinya yang ada di dalam BMIS. Dari uraian di atas, maka penelitian ini dibatasi pada fonologi BMIS.

Tujuan yang ingin dicapai di dalam penelitian ini ada tiga. Pertama, untuk mendeskripiskan bunyi-bunyi bahasa dan menggambarkan peta bunyi bahasa yang terdapat dalam bahasa Minangkabau isolek Sikucur. Kedua, untuk menguraikan fonem-fonem yang terdapat dalam bahasa Minangkabau isolek Sikucur dan 
membuat peta fonem. Terakhir, untuk memaparkan distribusi fonem-fonem yang terdapat dalam bahasa Minangkabau isolek Sikucur.

Hasil penelitian ini diharapkan bermanfaat terhadap pengembangan kajian ilmu bahasa, khususnya di bidang fonologi. Berikutnya, hasil penelitian ini bermanfaat untuk memberikan sumbangsih ilmu pengetahuan mengenai keberagaman bahasa Minangkabau. Temuan penelitian ini juga memperkaya kajian kebahasaan khususnya mengenai sistem fonem fonologi BMIS. Dengan adanya penelitian mengenai fonologi BMIS, hal ini diharapkan bisa menambah ilmu dan wawasan bagi peneliti berikutnya yang ingin meneliti mengenai fonologi bahasabahasa lainnya. Selanjutnya, diharapkan kajian fonologi yang membahas bunyi dan fonem ini juga dapat bermanfaat bagi kajian-kajian linguistik lainnya yang terkait dengan kajian ini. Selain itu, hasil penelitian ini juga diharapkan dapat bermanfaat bagi masyarakat lokal untuk melestarikan isolek yang digunakan di daerah tersebut sehingga isolek tersebut bisa terdokumentasikan.

\section{B. METODE}

Penelitian ini secara umum merupakan penelitian kualitatif yang bersifat deskriptif. Ada dua metode yang digunakan dalam mengumpulkan data, yaitu metode cakap dan metode simak. Langkah-langkah yang dilakukan dalam mengumpulkan data di lapangan ialah peneliti datang langsung ke daerah penelitian dan mewawancarai secara langsung tiga orang yang memenuhi syarat menjadi informan. Dalam memperoleh data, digunakan daftar pertanyaan yang telah dirancang oleh Nadra dan Reniwati (2009). Jumlah keseluruhan daftar pertanyaan ini adalah 864 daftar pertanyaan, namun daftar pertanyaan tersebut direduksi menjadi 744 daftar pertanyaan. Hal ini karena 120 pertanyaan lainnya adalah pertanyaan yang berhubungan dengan morfologi. Selain itu, daftar pertanyaan lainnya yang memungkinkan munculnya pasangann minimal juga ditambahkan guna mempermudah peneliti untuk mencari fonem yang terdapat dalam BMIS.

Selanjutnya, teknik pancing dalam metode cakap dilakukan guna memancing munculnya percakapan antara peneliti dan informan. Selama wawancara berlangsung, penggunaan bahasa yang diteliti disimak dan diamati. Hasil wawancara direkam dengan menggunakan aplikasi kamera yang ada di handphone dan dicatat dengan transkripsi fonetisnya berdasarkan IPA chart. Setelah data terkumpul, langkah yang selanjutnya dilakukan adalah memindahkan data yang direkam ke komputer untuk didengar dan dicek kembali.

Setelah semua data yang dperlukan untuk penelitian telah terkumpul, selanjutnya langkah yang dilakukan adalah menganalisis data. Metode yang digunakan untuk menganalisis data adalah metode padan fonetis artikulatoris. Teknik dasar yang digunakan adalah teknik pilah unsur penentu dan teknik lanjutannya ialah teknik lanjutan fonetis artikulatoris. Data yang telah diperoleh diklasifikasikan sesuai dengan kelompok bunyinya, seperti bunyi vokoid, bunyi diftong, dan bunyi kontoid. Sementara, untuk menentukan fonem yang ada di BMIS, dibuat daftar pasangan bunyi yang memiliki kemiripan secara fonetis. Fonem-fonem yang ditemukan dikelompokkan ke dalam fonem vokal, fonem diftong, dan fonem konsonan. Selanjutnya, data tersebut diuraikan sesuai dengan distribusinya dengan memerhatikan posisi fonem yang berada di awal, tengah, atau akhir kata.

Terakhir, data yang telah dianalisis disajikan dengan dua metode, yakni metode formal dan informal. Tujuan penggunaan lambang-lambang dalam 
penyajian data adalah agar penjelasan hasil yang diperoleh bisa lebih ringkas dan padat. Pada metode formal, data diuraikan dengan menggunakan tanda dan lambang, misalnya [...] kurung siku yang digunakan untuk mengapit unsur fonetis, /.../ garis miring yang dipakai untuk mengapit unsur fonemis, '...' tanda kutip untuk mengapit makna suatu unsur atau terjemahan, beserta lambang linguistik lainnya yang berhubungan dengan data yang diperoleh. Sementara, pada metode informal, data tersebut dideskripsikan dengan menggunakan kata-kata biasa.

\section{PEMBAHASAN}

Berikut ini dibahas mengenai bunyi, fonem, dan distribusinya yang ditemukan dalam BMIS. Pada bagian pertama, dideskripsikan bunyi-bunyi yang diperoleh dari data di lapangan dan menyertakan peta bunyi. Bagian kedua membahas mengenai fonem-fonem yang ada di BMIS serta peta fonem. Terakhir, diuraikan distribusi fonem-fonem tersebut.

\section{Bunyi-bunyi Bahasa Minangkabau Isolek Sikucur}

Ada tiga klasifikasi bunyi bahasa yang ditemukan di BMIS. Bunyi-bunyi tersebut dikelompokkan ke dalam bunyi vokoid, bunyi diftong, dan bunyi kontoid. Secara keseluruhan terdapat 38 jumlah bunyi yang diperoleh, yaitu terdiri atas 10 bunyi vokoid, 9 bunyi diftong, dan 19 bunyi kontoid. Bunyi vokoid yang terdapat dalam BMIS ialah [i], $[\mathrm{I}],[\mathrm{e}],[\varepsilon],[\mathrm{a}],[\Lambda],[\mathrm{u}],[\mathrm{v}],[\mathrm{o}]$, dan [o]. Sementara, bunyi diftong yang ditemukan adalah [aw], [ay], [ie], [ue], [uy], [ua], [ia], [oy], dan [ea]. Terakhir, bunyi kontoid yang diperoleh ialah $[\mathrm{p}],[\mathrm{b}],[\mathrm{m}],[\mathrm{t}],[\mathrm{d}],[\mathrm{n}],[1],[\mathrm{s}],[\mathrm{c}],[\mathrm{j}]$, $[\mathrm{n}],[\mathrm{k}],[\mathrm{g}],[\mathrm{R}],[\mathrm{y}],[\mathrm{h}],[?],[\mathrm{w}]$, dan $[\mathrm{y}]$.

\section{a. Bunyi Vokoid}

Ada 10 bunyi vokoid yang ditemukan di dalam BMIS, yaitu [i], [I], [e], [e], [a], $[\Lambda],[u],[\mho],[o]$, dan [o]. Contoh kata-kata dalam BMIS yang memiliki bunyi-bunyi vokoid tersebut bisa dilihat di bawah ini.

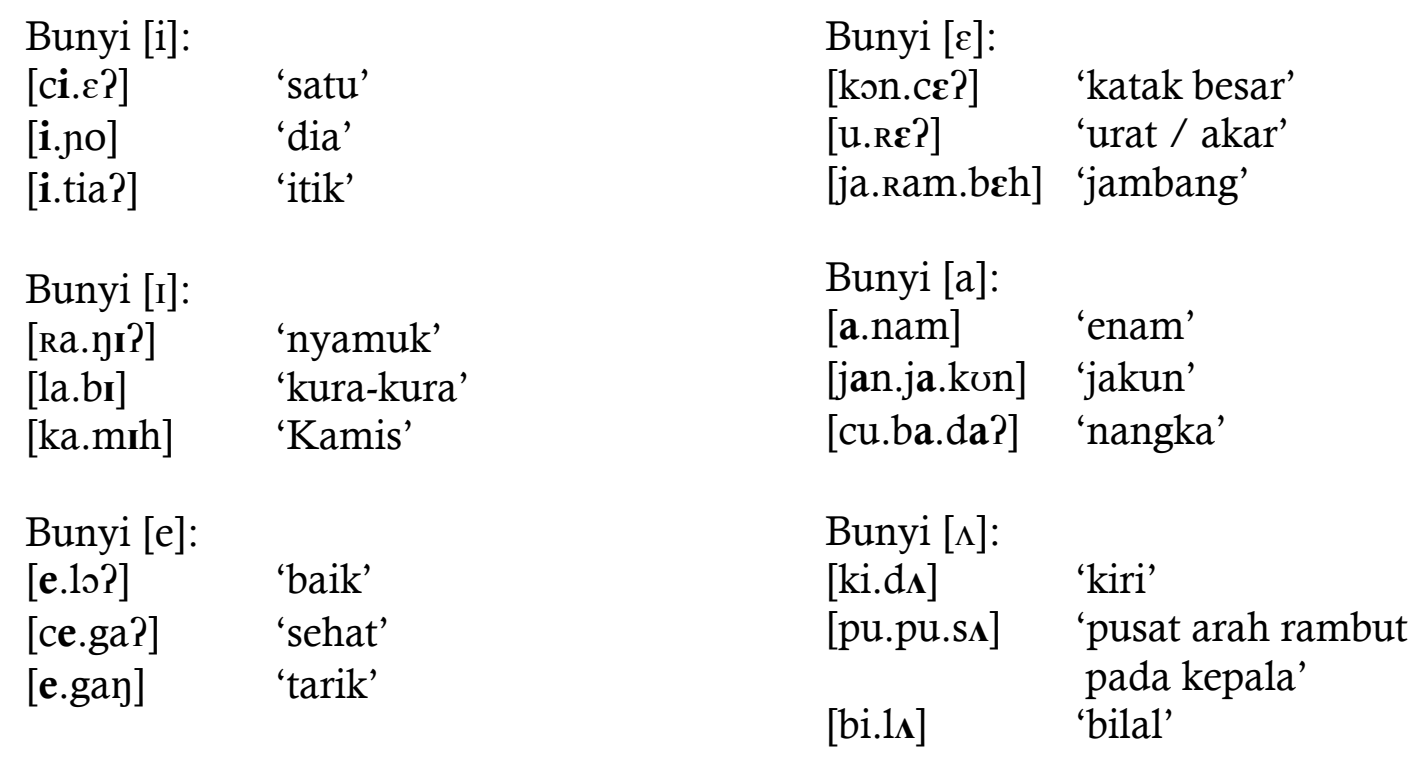




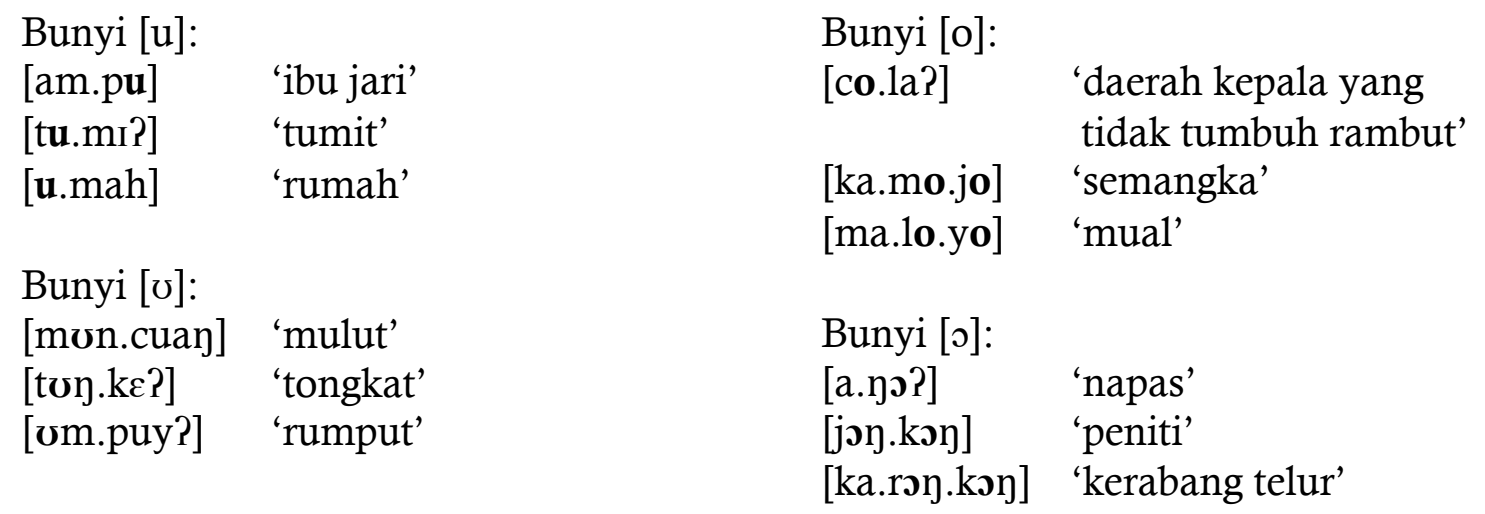

Bersumber dari data di atas, dapat diperoleh kesimpulan bahwa bunyi [i] dan $[\mathrm{I}]$, [e] dan $[\varepsilon]$, [a] dan $[\Lambda],[\mathrm{u}]$ dan $[\mho]$, serta [o] dan [o] muncul pada lingkungan yang berbeda. Bunyi [i] dan [e] muncul pada silabel awal dan juga pada silabel tengah terbuka maupun tertutup. Sementara, untuk bunyi [I] dan $[\varepsilon]$ muncul pada silabel akhir terbuka dan tertutup, serta muncul sebelum [?] dan [h]. Selanjutnya, bunyi [a] muncul pada silabel awal dan muncul pada silabel tengah terbuka dan tertutup. Sementara, bunyi [a] menjadi lemah pada silabel akhir terbuka menjadi $[\Lambda]$. Bunyi [u] dan [o] muncul pada setiap suku kata, suku kata awal, tengah, dan akhir. Apabila bunyi $[\mathrm{u}]$ berdekatan dengan nasal $[\mathrm{m}]$, [n], dan [n], ia cenderung melemah menjadi bunyi [ซ]. Sementara, bunyi [o] melemah menjadi [0] jika muncul sebelum glotal [?] dan [h] dan berdekatan dengan nasal [m], [n], dan [n]. Adapun peta bunyi vokoid dapat dilihat pada Tabel 1.

\section{b. Bunyi Diftong}

Bunyi diftong yang ditemukan dalam BMIS ada sebanyak 9 buah. Bunyi-bunyi diftong tersebut adalah [aw], [ay], [ie], [ue], [uy], [ua], [ia], [oy], dan [ea]. Berikut ini adalah contoh kata-kata dalam BMIS yang mempunyai bunyi-bunyi diftong tersebut.

\begin{tabular}{|c|c|c|c|}
\hline $\begin{array}{l}\text { Bunyi [aw]: } \\
\text { la.naw] }\end{array}$ & 'lalat' & [ku.hue] & 'batuk' \\
\hline [Ri.maw] & 'harimau' & & \\
\hline [Ra.baw?] & 'rebab' & $\begin{array}{l}\text { Bunyi [uy]: } \\
\text { [u.suyh] }\end{array}$ & 'usus' \\
\hline Bunyi [ay]: & & [su.puy?] & 'kumis' \\
\hline $\begin{array}{l}\text { [ga.layh] } \\
\text { [se.hay?] }\end{array}$ & $\begin{array}{l}\text { 'gelas' } \\
\text { 'sehat' }\end{array}$ & [mi.nu.kuy?] & 'beras kecil' \\
\hline [ka.su.nay] & 'kencing' & $\begin{array}{l}\text { Bunyi [ua]: } \\
\text { [da.gua?] }\end{array}$ & 'dagu' \\
\hline Bunyi [ie]: & & [min.ka.ruan] & ]'kadal' \\
\hline [i.lie] & 'selatan' & [bu.luah] & 'buluh' \\
\hline [a.yie] & 'air' & & \\
\hline [an.die] & 'bodoh' & & \\
\hline Bunyi [ue]: & & $\begin{array}{l}\text { Bunyi [ia]: } \\
\text { [mu.dia?] }\end{array}$ & 'utara' \\
\hline [ta.lue] & 'telur' & [tan.gian] & 'gigi yang menonjol \\
\hline
\end{tabular}


[ca.miah] 'nyaris'

Bunyi [ea]:

[lo.teay] 'loteng'

Bunyi [oy]:

[oy] 'hai'

Berdasarkan paparan hasil data bunyi diftong di atas, dapat diambil kesimpulan bahwa hampir semua bunyi diftong yang ditemukan di BMIS muncul pada silabel akhir, kecuali pada diftong [oy] yang bisa muncul pada silabel awal. Bunyi [aw] muncul dalam silabel akhir terbuka, Berikutnya, bunyi [aw] ini juga muncul sebelum glotal [?]. Sementara, bunyi [ay] muncul pada silabel akhir terbuka dan muncul sebelum glotal [?] dan [h]. Lain lagi dengan bunyi [ie] dan [ue] yang hanya muncul pada silabel akhir terbuka saja. Hal ini berbeda dengan bunyi diftong [ia], [uy] dan [ua] yang hanya terdapat pada silabel akhir tertutup dan muncul sebelum glotal [?]. Bunyi [ia], [uy] dan [ua] juga bisa berada sebelum bunyi [h]. Selain itu, bunyi [ia] dan [ua] bisa muncul sebelum [n]. Terakhir, bunyi [ea] muncul pada silabel akhir tertutup dan berdekatan dengan [y]. Berikut peta bunyi diftong dalam BMIS yang bisa diamati pada Tabel 2 .

\section{c. Bunyi Kontoid}

Dalam BMIS, ada terdapat 19 bunyi kontoid yang ditemukan. Bunyi-bunyi kontoid dalam BMIS tersebut adalah [p], [b], [m], [t], [d], [n], [1], [s], [c], [j], [n], [k], $[\mathrm{g}],[\mathrm{R}],[\mathrm{y}],[\mathrm{h}],[\mathrm{?}],[\mathrm{w}]$, dan [y]. Di bawah ini dipaparkan contoh kata-kata dalam BMIS yang memiliki bunyi-bunyi kontoid.

Bunyi $[p]$ :

[ka.pa.tan]

[pi.pih] 'pipi'

[pa.rah] 'peras'

Bunyi $[b]$ :

[am.ban] 'setagen'

[bu.luah] 'buluh'

[ba.bu.wu] 'berburu'

Bunyi [m]:

[an.ti.mon] 'mentimun'

[Rim.bo] 'hutan'

[li.mo.mo] 'ketombe'

Bunyi [t]:

[ta.li.no]

[lu.tuan]

[tu.duan]

Bunyi [d]:

[da.Re?]

[a.den]

[du.kuah

$\begin{array}{ll}\text { Bunyi [n]: } & \\ \text { [na.nay] } & \text { 'rayap' } \\ \text { [an.jian] } & \text { 'anjing' } \\ \text { [in.je?] } & \text { 'angkat' }\end{array}$

Bunyi [1]:

[la.wuy?] 'laut'

[ka.re.kel] 'kerikil'

[co.la?] 'daerah kepala yang

tidak tumbuh rambut'

Bunyi [r]:

[ta.rom.p $\Lambda$ 'alas kaki'

[da.ro.pon] 'lobang angin

(ventilasi)'

[ka.ra.jo] 'bekerja'

Bunyi [s]:

[sa.Rian] 'gigi taring'

[u.suyh] 'usus'

[sa.la.s $\Lambda$ 'Selasa' 


\begin{tabular}{|c|c|c|c|}
\hline $\begin{array}{l}\text { Bunyi }[\mathrm{c}]: \\
\text { [ca.ko] } \\
\text { [mon.cuan] } \\
\text { [cin.kua?] }\end{array}$ & $\begin{array}{l}\text { 'baru-baru ini' } \\
\text { 'mulut' } \\
\text { 'bengkok' }\end{array}$ & $\begin{array}{l}\text { Bunyi [R]" } \\
\text { [Ra.Ra.mo] } \\
\text { [Ru.biay] } \\
\text { [ka.re?] }\end{array}$ & $\begin{array}{l}\text { 'kupu-kupu' } \\
\text { 'cakar' } \\
\text { 'potong' }\end{array}$ \\
\hline $\begin{array}{l}\text { Bunyi [j]: } \\
\text { [jan.ja.kon] } \\
\text { [jayh] } \\
\text { [jin.jian] }\end{array}$ & $\begin{array}{l}\text { 'jakun' } \\
\text { 'jas' } \\
\text { 'jinjing }\end{array}$ & $\begin{array}{l}\text { Bunyi }[\mathrm{y}] \text { : } \\
\text { [su.puy?] } \\
\text { [a.po?] } \\
\text { [on.ku] }\end{array}$ & $\begin{array}{l}\text { 'kumis' } \\
\text { 'napas' } \\
\text { 'ayah dari orang tua' }\end{array}$ \\
\hline $\begin{array}{l}\text { Bunyi }[\mathrm{n}] \text { : } \\
\text { [i.jno] } \\
\text { [i.jnia?] } \\
\text { [a.jie] }\end{array}$ & $\begin{array}{l}\text { 'dia' } \\
\text { 'kakek dari kakek/ } \\
\text { nenek' } \\
\text { 'anyir (bau darah } \\
\text { kental)' }\end{array}$ & $\begin{array}{l}\text { Bunyi }[\mathrm{h}] \text { : } \\
{[\text { a.tah] }} \\
{[\text { la.weh] }} \\
\text { [ja.niah] }\end{array}$ & $\begin{array}{l}\text { 'ukuran padi terkecil' } \\
\text { 'lebar' } \\
\text { 'jernih' }\end{array}$ \\
\hline $\begin{array}{l}\text { Bunyi [k]: } \\
\text { [ka.Ruy?] } \\
\text { [si.ke?] }\end{array}$ & $\begin{array}{l}\text { kental)' } \\
\text { 'rambut ikal' } \\
\text { 'sisir' }\end{array}$ & $\begin{array}{l}\text { [ju.nuy?] } \\
\text { [ka.ti.ya?] } \\
\text { [ba.bi.ya?] }\end{array}$ & $\begin{array}{l}\text { 'mata susu' } \\
\text { 'ketiak' } \\
\text { 'basah' }\end{array}$ \\
\hline $\begin{array}{l}\text { [min.ka.ruan] } \\
\text { Bunyi [g]: } \\
\text { [ga.ra.man] } \\
\text { [pon.guan] } \\
\text { [ga.reh] }\end{array}$ & $\begin{array}{l}\text { 'geraham' } \\
\text { 'punggung' } \\
\text { 'jatuh (buah)' }\end{array}$ & $\begin{array}{l}\text { Bunyi [w]: } \\
\text { [ja.wi] } \\
\text { [sa.ra.ws] } \\
\text { [ka.la.la.ws] } \\
\text { Bunyi [y]: } \\
\text { [sa.na.yan] } \\
\text { [ka.pu.yua?] } \\
\text { [sa.yue] }\end{array}$ & $\begin{array}{l}\text { 'sapi' } \\
\text { 'celana' } \\
\text { 'kelelawar' }\end{array}$ \\
\hline
\end{tabular}

Berdasarkan data bunyi kontoid di atas, dapat disimpulkan bahwa bunyi [?] merupakan realisasi dari bunyi [k] apabila berada di silabel akhir tertutup. Contohnya bisa dilihat dalam kata [pi.yuy?] yang artinya 'cucu dari cucu'. Selanjutnya, $[\mathrm{R}]$ dan $[\mathrm{r}]$ merupakan variasi bebas dan tidak membedakan makna. Keduanya bisa muncul pada lingkungan yang sama karena tidak ada lingkungan tertentu yang mempengaruhi munculnya bunyi tersebut. $[\mathrm{R}]$ dan $[\mathrm{r}]$ dapat digunakan pada suku kata awal, seperti pada kata [Ru.bian] dan [ru.bian] yang bermakna 'cakar' dan juga berada di tengah kata, misalnya dalam kata [ga.RIn] dan [ga.rin] yang berarti 'garim'. Berikutnya, peta bunyi kontoid bisa dilihat di Tabel 3.

\section{Fonem-fonem dalam Bahasa Minangkabau Isolek Sikucur}

Untuk menentukan fonem-fonem yang ada dalam BMIS dibutuhkan prosedur, seperti mencari pasangan minimal, distribusi komplementer, dan variasi bebas. Analisis data dilakukan dengan cara (1) mencatat kata-kata yang mirip secara fonetis, (2) mencatat bunyi-bunyi atau kata-kata yang berlainan, (3) mencatat bunyi-bunyi yang mirip atau sama yang dianggap sebagai fonem yang berbeda, dan (4) mencatat beberapa bunyi yang berada di distribusi komplementer dan bebas. Setelah fonem- 
fonem dalam BMIS diperoleh, selanjutnya fonem-fonem tersebut dikelompokkan ke dalam peta fonem vokal, diftong, dan konsonan.

\section{a. Fonem Vokal}

Terdapat 5 fonem vokal yang ditemukan dalam BMIS. Fonem vokal tersebut adalah /i/, /e/, /a/, /u/, dan /o/. Berikut pembuktian fonem vokal yang diperoleh dari data BMIS dengan melihat pasangan minimal dan distribusi komplementernya.

\begin{tabular}{|c|c|c|c|c|c|}
\hline /i/ dan /e/: & [ba.tıh] & 'betis' & $\sim$ & [ba.teh] & 'batas' \\
\hline /e/ dan /a/: & [da.reh] & 'deras' & $\sim$ & [da.rah] & 'darah' \\
\hline /a/dan /i/: & [a.lie] & 'licin' & $\sim$ & [i.lie] & 'selatan' \\
\hline$/ \mathrm{u} /$ dan $/ \mathrm{a} /:$ & [bu.rua?] & 'buruk' & $\sim$ & [ba.Rua?] & 'monyet' \\
\hline /o/ dan /e/: & [a.co?] & 'sering' & $\sim$ & [а.ск?] & 'lintah' \\
\hline
\end{tabular}

Setiap fonem vokal ini mempunyai alofon yang digunakan pada lingkungan tertentu. Fonem /i/ direalisasikan sebagai [i] apabila terdapat di awal kata dan jika didahului oleh konsonan (pada suku terbuka) atau di antara konsonan (pada suku tertutup). Sementara, /i/ direalisasikan sebagai [I] jika berada di akhir kata terbuka maupun tertutup serta muncul sebelum [?] dan [h]. Dengan demikian, dapat dikatakan bahwa fonem /i/ dalam BMIS mempunyai alofon [i] dan [I].

Fonem /e/ direalisasikan sebagai [e] apabila terdapat di awal kata dan jika didahului oleh konsonan (pada suku terbuka) atau di antara konsonan (pada suku tertutup). Sementara, /e/ direalisasikan sebagai $[\varepsilon]$ jika berada di akhir kata terbuka maupun tertutup serta muncul sebelum [?] dan [h]. Dengan demikian, dapat dikatakan bahwa fonem /e/ dalam BMIS mempunyai alofon [e] dan [ $\varepsilon$ ].

Berikutnya, fonem /a/ direalisasikan sebagai [a] jika terdapat di awal kata dan apabila berada setelah konsonan serta di antara dua konsonan. Selanjutnya, /a/ direalisasikan sebagai $[\Lambda]$ apabila berada di akhir kata terbuka. Jadi, fonem /a/ dalam BMIS disimpulkan memiliki dua alofon, yaitu [a] dan $[\Lambda]$.

Sementara, fonem $/ \mathrm{u} /$ direalisasikan sebagai $[\mathrm{u}$ ] jika berada di semua posisi suku kata, baik suku kata awal, tengah, maupun akhir. Sementara, /u/ direalisasikan sebagai [v] apabila muncul sebelum maupun sesudah nasal [m], [n], dan [n], baik itu pada posisi suku kata awal, tengah, ataupun akhir. Jadi, dalam BMIS fonem $/ \mathrm{u}$ / dikatakan mempunyai alofon [u] dan [v].

Terakhir, Fonem /o/ direalisasikan sebagai [o] apabila berada pada semua posisi suku kata, baik suku kata awal, tengah, maupun akhir. Sementara, /o/ direalisasikan sebagai [0] jika muncul sebelum glotal [?] dan [h] serta berada sebelum maupun sesudah nasal [m], [n], dan [n]. Dengan demikian, di dalam BMIS fonem /o/ dinyatakan memiliki dua alofon, yakni [o] dan [0]. Untuk peta fonem vokal dapat diamati dari Tabel 4.

\section{b. Fonem Diftong}

Dalam BMIS diperoleh 7 fonem diftong. Fonem-fonem diftong tersebut ialah /ia/, /ua/, /aw/, /ay/, /uy/, /oy/, dan /ea/. Berikut pembuktian fonem diftong yang didapat dari data BMIS dengan melihat pasangan minimal dan distribusi komplementer serta lingkungan yang mirip. 


\begin{tabular}{|c|c|c|c|c|c|}
\hline /ia/dan /ua/: & [bu.liah] & 'boleh' & $\sim$ & [bu.luah] & 'buluh' \\
\hline /ua/dan /ia/ & [ma.sua?] & 'masuk' & $\sim$ & [ma.sia?] & 'kering' \\
\hline /aw/dan /ue/: & [ka.saw] & 'kasau' & $\sim$ & [ka.sue] & 'kasur' \\
\hline /ay/dan /ie/: & [a.lay] & 'helai' & $\sim$ & [a.lie] & 'licin' \\
\hline /uy/dan /ua/: & [du.duy?] & 'hisap' & $\sim$ & [du.dua?] & 'duduk' \\
\hline /ea/ dan /ua/: & [lo.tean] & 'loteng' & $\sim$ & [lu.tuay] & 'lutut' \\
\hline /oy/dan /aw/: & [oy] & 'hai' & $\sim$ & [aw] & 'aduh' \\
\hline
\end{tabular}

Fonem /ia/ direalisasikan sebagai [ia] apabila terdapat pada suku kata akhir tertutup, sebelum glotal [?] dan [h], serta sebelum nasal [y]. Sementara, /ia/ direalisasikan sebagai [ie] apabila berada di akhir kata terbuka. Jadi, fonem /ia/ dalam BMIS disimpulkan memiliki dua alofon, yaitu [ia] dan [ie]. Sementara, fonem /ua/ direalisasikan sebagai [ua] jika berada pada suku kata akhir tertutup, sebelum glotal [?] dan [h], serta sebelum nasal [n]. Sementara, /ua/ direalisasikan sebagai [ue] apabila muncul pada suku akhir kata terbuka. Dengan demikian, dapat disimpulkan bahwa dalam BMIS fonem /ua/ mempunyai dua alofon, yakni [ua] dan [ue]. Peta fonem diftong dapat dilihat pada Tabel 5.

\section{c. Fonem Konsonan}

Fonem konsonan yang didapat dari BMIS ada sebanyak 18. Fonem-fonem konsonan tersebut adalah /p/, /b/, /m/, /t/, /d/, /n/, /1/, /R/, /s/, /c/, /j/, /n/, $/ \mathrm{k} /, / \mathrm{g} /, / \mathrm{y} /, / \mathrm{h} /, / \mathrm{w} /$, dan $/ \mathrm{y} /$. Pembuktian fonem-fonem tersebut dilakukan dengan mencari pasangan minimal dan distribusi komplementer.

\begin{tabular}{|c|c|c|c|c|c|}
\hline$/ \mathrm{p} / \mathrm{dan} / \mathrm{b} /:$ & [um.puy?] & 'rumput' & $\sim$ & [um.buy?] & 'umbut' \\
\hline /b/ dan /d/: & [ba.RE?] & 'berat' & $\sim$ & [da.RE?] & 'timur' \\
\hline$/ \mathrm{m} /$ dan $/ \mathrm{k} /:$ & [ma.sia?] & 'kering' & $\sim$ & [ka.sia?] & 'pasir' \\
\hline$/ \mathrm{d} / \mathrm{dan} / \mathrm{n} /:$ & [pa.deh] & 'pedas' & $\sim$ & [pa.nch] & 'panas' \\
\hline$/ \mathrm{t} / \mathrm{dan} / \mathrm{j} /:$ & [tayh] & 'tas' & $\sim$ & [jayh] & 'jas' \\
\hline$/ \mathrm{n} / \operatorname{dan} / \mathrm{R} /:$ & [na.nay] & 'rayap' & $\sim$ & [Ra.nay] & 'hujan gerimis' \\
\hline /1/ dan /R/: & [u.le?] & 'ulat' & $\sim$ & [u.Re?] & 'akar' \\
\hline /R/ dan /s/: & [bu.rua?] & 'buruk' & $\sim$ & [bu.sua?] & 'busuk' \\
\hline /s/ dan $/ \mathrm{j} /:$ & [sa.riay] & 'gigi taring' & $\sim$ & [ja.riay] & 'jengkol' \\
\hline$/ \mathrm{c} / \operatorname{dan} / 1 /$ : & [ca.wua?] & 'gayung' & $\sim$ & [la.wua?] & 'ikan’ \\
\hline$/ \mathrm{j} /$ dan $/ \mathrm{p} /:$ & [ja.yı?] & 'jahit' & $\sim$ & [pa.yı?] & 'pahit' \\
\hline$/ \mathrm{n} / \operatorname{dan} / 1 /:$ & [a.jie] & 'anyir' & $\sim$ & [a.lie] & 'licin' \\
\hline$/ \mathrm{k} / \mathrm{dan} / 1 /$ : & [ku.ruyh] & 'kurus' & $\sim$ & [lu.ruyh] & 'lurus' \\
\hline /g/ dan /k/: & [pan.gue] & 'panggul' & $\sim$ & [pay.kue] & 'cangkul' \\
\hline$/ \mathrm{y} / \mathrm{dan} / \mathrm{t} /:$ & [a.yo?] & 'napas' & $\sim$ & [a.to?] & 'atap' \\
\hline /h/ dan /y/: & [a.suah] & 'asuh' & $\sim$ & [a.suan] & 'hasut' \\
\hline /w/ dan /p/: & [a.wuyh] & 'haus' & $\sim$ & [a.puyh] & 'hapus' \\
\hline /y/dan /n/: & [a.yam] & 'ayam' & $\sim$ & [a.nam] & 'enam' \\
\hline
\end{tabular}




\section{Distribusi Fonem Bahasa Minangkabau Isolek Sikucur \\ a. Distribusi Fonem Vokal}

Distribusi vokal yang terdapat dalam BMIS dapat dikatakan menduduki semua posisi kata, yakni berada di awal kata, tengah kata, dan akhir kata. Hal ini bisa diperhatikan dari rincian distribusi fonem vokal yang tertera pada Tabel 7.

\section{b. Distribusi Fonem Diftong}

Dalam BMIS, ada dua fonem diftong yang bisa muncul pada awal kata, yaitu /oy/ dan /aw/. Diftong /oy/ hanya ditemukan pada posisi awal kata saja dan tidak pernah berada pada posisi tengah maupun akhir kata. Hal ini berbeda dengan diftong /aw/ yang bisa menduduki semua posisi suku kata, baik di awal, tengah, dan akhir kata. Sementara, diftong /uy/ dan /ea/ hanya berada pada posisi tengah kata saja. Selain itu, diftong /ia/ dan /ua/ juga bisa berada pada posisi tengah kata. Selanjutnya, [ie] yang merupakan realisasi dari /ia/ dan [ue] yang merupakan realisasi dari /ua/ hanya muncul pada posisi akhir kata saja. Penjabaran dan contoh kata-kata mengenai distribusi fonem diftong dalam BMIS dapat diamati pada Tabel 8.

\section{c. Distribusi Fonem Konsonan}

Berdasarkan hasil analisis data mengenai distribusi konsonan yang terdapat dalam BMIS, tidak semua konsonan menduduki semua posisi kata awal, tengah, dan akhir. Dari data yang diperoleh hanya ada 4 konsonan yang menempati semua posisi kata, yaitu /m/, /n/, /1/, dan /g/. Sementara, konsonan lainnya /p/, /b/, /t/, /d/, $/ \mathrm{R} /, / \mathrm{s} /, / \mathrm{c} /, / \mathrm{j} /, / \mathrm{n} /, / \mathrm{g} /, / \mathrm{w} /$, dan $/ \mathrm{y} /$ hanya menempati posisi awal dan tengah kata saja. Selanjutnya, fonem /k/ direalisasikan sebagai glotal [?] apabila berada di belakang suku kata. Hal ini berbeda dengan konsonan /h/ yang tidak ditemukan pada posisi awal kata. Uraiannya dapat dilihat pada Tabel 9.

Analisis data mengenai fonologi BMIS ini menunjukkan adanya persamaan dan perbedaan dengan bahasa Minangkabau umum dan bahasa Minangkabau yang sudah lebih dahulu diteliti di daerah lain. Dapat disimpulkan bahwa secara fonemis BMIS dan bahasa Minangkabau umum memiliki jumlah fonem yang sama, yaitu /i/, /e/, /a/, /u/, dan /o/. Namun, secara fonetis, BMIS mempunyai jumlah yang berbeda. Hal ini terlihat dari hasil penelitian Almos (2012) yang menyatakan bahwa terdapat 9 bunyi vokoid dalam bahasa Minangkabau, yaitu [a], [i], [u], [e], [o] [I], $[\mho],[\varepsilon]$, dan [o]. Sementara, dalam BMIS ditemukan alofon lain, yaitu $[\Lambda]$, yang berada pada suku kata akhir terbuka. Jadi, ada 10 bunyi vokoid yang diperoleh dalam BMIS.

Selanjutnya, ada persamaan jumlah diftong yang ditemukan dalam BMIS dengan bahasa Minangkabau secara umum, yaiut sama-sama berjumlah 7 diftong. Menurut Ayub et al. (1993), diftong dalam bahasa Minangkabau secara umum ialah /ia/, /ua/, /ea/, /uy/, /oy/, /aw/, dan /ay/. Perbedaannya ialah ditemukannya alofon pada diftong /ia/ dan /ua/ yang mana dalam bahasa Minangkabau secara umum diftong-diftong tersebut tidak mempunyai alofon. Dalam BMIS, diftong /ia/ mempunyai alofon [ia $\sim$ ie] dan diftong /ua/ mempunyai alofon [ua $\sim$ ue].

Terakhir, konsonan secara fonemis dalam BMIS mempunyai jumlah yang sama dengan konsonan yang ada di bahasa Minangkabau secara umum. Seperti yang dipaparkan oleh Almos (2012), fonem konsonan dalam bahasa Minangkabau adalah

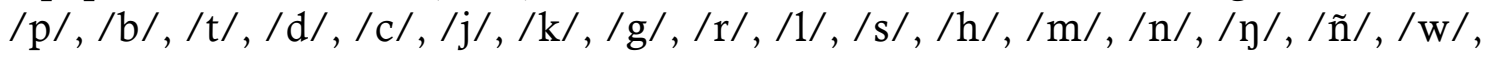


dan /y/. Namun, perbedaannya di dalam BMIS yang ditemukan adalah adanya penggunaan / R/. Hal ini serupa dengan hasil penelitian Rahmadani et al. (2013) yang menyatakan bahwa adanya penggunaan / $/$ / dalam beberapa kata di dalam bahasa Minangkabau di Kenagarian Sinuruik.

\section{PENUTUP}

Kesimpulan yang bisa diambil dari penelitian ini adalah secara fonemis adanya 5 vokal yang ditemukan dalam BMIS, yaitu /i/, /e/, /a/, /u/, dan /o/ yang berdistribusi lengkap. Sementara, secara fonetis ada bunyi 10 vokoid, yakni [i], [e], $[\mathrm{a}],[\mathrm{u}],[\mathrm{o}],[\mathrm{I}],[\varepsilon],[\Lambda],[\mho]$, dan $[0]$. Selanjutnya, diftong yang terdapat di BMIS berjumlah 7, yaitu /ia/, /ea/, /au/, /ay/, /ua/, /oy/, dan/uy/. Diftong /ia/ mempunyai alofon [ia $\sim$ ie], sedangkan diftong /ua/ memiliki alofon [ua $\sim$ ue]. Dari semua fonem diftong ini, hanya ada satu diftong yang berdistribusi lengkap, yaitu diftong /aw/. Sementara, untuk diftong-diftong lainnya hanya bisa menduduki satu atau dua posisi suku kata saja. Terakhir, fonem konsonan dalam BMIS ada sebanyak 18, yakni /p/, /b/, /m/, /t/, /d/, /n/, /1/, /R/, /s/, /c/, /j/, /n/, /k/, /g/, /g/, $/ \mathrm{h} /, / \mathrm{w} /$, dan /y/. Dalam BMIS, [R] dan [r] merupakan variasi bebas karena tidak ada lingkungan tertentu yang mempengaruhi munculnya dua bunyi ini dan kedua bunyi ini juga tidak membedakan makna. Berikutnya, /k/ direalisasikan sebagai [?] apabila berada di belakang suku kata akhir.

Selanjutnya, penelitian ini merupakan penelitian sinkronis mengenai bunyi dan sistem fonem yang terdapat dalam bahasa Minangkabau isolek Sikucur. Untuk itu, disarankan bagi peneliti bahasa untuk bisa melakukan penelitian lebih lanjut guna mengembangkan hasil penelitian yang sudah ada sehingga penelitian tentang bahasa Minangkabau isolek Sikucur ini bisa lebih lengkap dan memberikan manfaat yang lebih banyak untuk penelitian-penelitian lainnya. Selain itu, disarankan juga bagi pemerhati bahasa agar penelitian ini dapat dikembangkan sesuai dengan ilmu yang bersangkutan serta bisa menjadi dasar untuk kajian-kajian linguistik lainnya, seperti dialektologi, morfologi, sintaksis, dan kajian makrolinguistik lainnya. Terakhir, disarankan bagi lembaga pendidikan agar mengumpulkan data hasil penelitian bahasa untuk kelengkapan data dan informasi di bidang pendidikan. 
Tabel 1. Peta Vokoid

\begin{tabular}{|c|c|c|c|}
\hline Posisi & Depan & Tengah & Belakang \\
\hline Tinggi Atas & $\mathrm{i}$ & & $\mathrm{u}$ \\
\hline Tinggi Bawah & I & & $\mho$ \\
\hline Menengah Atas & $\mathrm{e}$ & & $\mathrm{o}$ \\
\hline Menengah Bawah & $\varepsilon$ & & o \\
\hline Rendah & $\mathrm{a}$ & & $\Lambda$ \\
\hline
\end{tabular}

\section{Tabel 2. Peta Diftong}

Posisi

Tinggi Atas

Tinggi Bawah

Menengah Atas

Menengah Bawah

Rendah

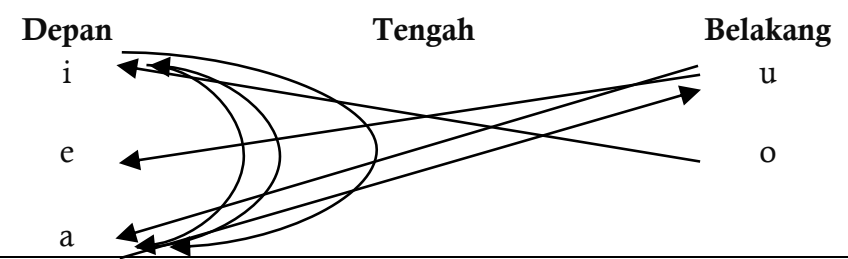

Tabel 3. Peta Kontoid

\begin{tabular}{|c|c|c|c|c|c|c|c|}
\hline \multirow{3}{*}{ Hambat (Plosive) } & & Labial & Alveolar & Palatal & Velar & Uvular & Glotal \\
\hline & TS & $\mathrm{p}$ & $\mathrm{t}$ & c & $\mathrm{k}$ & & $?$ \\
\hline & BS & $b$ & $\mathrm{~d}$ & & $\mathrm{~g}$ & & \\
\hline Nasal & & $\mathrm{m}$ & $\mathrm{n}$ & $\mathrm{n}$ & $\eta$ & & \\
\hline Getar (Trill) & & & & & & $\mathrm{R}$ & \\
\hline Frikatif & TS & & $\mathrm{s}$ & & & & $\mathrm{h}$ \\
\hline Approximant & & & & $\mathrm{j}$ & & & \\
\hline Lateral & & & 1 & & & & \\
\hline Semi Vokal & & W & & $\mathrm{y}$ & & & \\
\hline
\end{tabular}

Keterangan: $\mathrm{BS}=$ bersuara $\mathrm{TS}=$ tidak bersuara

Tabel 4. Peta Vokal

\begin{tabular}{lccc}
\hline Posisi & Depan & Tengah & Belakang \\
\hline Tinggi Atas & $\mathrm{i}$ & $\mathrm{u}$ \\
Tinggi Bawah & $\mathrm{e}$ & $\mathrm{o}$ \\
Menengah Atas & & \\
Menengah Bawah & $\mathrm{a}$ & \\
Rendah & $\mathrm{a}$ &
\end{tabular}

Tabel 5. Peta Diftong

\begin{tabular}{llll}
\hline Posisi & Depan & Belakang \\
Tinggi Atas & Tengah \\
Tinggi Bawah & Menengah Atas \\
Menengah Bawah \\
Rendah
\end{tabular}

Tabel 6. Peta Konsonan

\begin{tabular}{lccccccc}
\hline & & Labial & Alveolar & Palatal & Velar & Uvular & Glotal \\
\hline Hambat (Plosive) & TS & $\mathrm{p}$ & $\mathrm{t}$ & $\mathrm{c}$ & $\mathrm{k}$ & & \\
Nasal & BS & $\mathrm{b}$ & $\mathrm{d}$ & & $\mathrm{g}$ & & \\
Getar (Trill) & & $\mathrm{m}$ & $\mathrm{n}$ & $\mathrm{n}$ & $\mathrm{n}$ & $\mathrm{h}$ & \\
$\begin{array}{l}\text { Frikatif } \\
\text { Approximant }\end{array}$ & TS & & $\mathrm{s}$ & & & \\
Lateral & & & $\mathrm{j}$ & & \\
Semi Vokal & & $\mathrm{w}$ & $\mathrm{y}$ & & \\
\hline Keterangan: BS = bersuara TS = tidak bersuara & &
\end{tabular}


Tabel 7. Distribusi Fonem Vokal

\begin{tabular}{|c|c|c|c|c|}
\hline \multirow[t]{2}{*}{ No } & \multirow[t]{2}{*}{ Fonem } & \multicolumn{3}{|c|}{ Distribusi Fonem Vokal } \\
\hline & & Awal & Tengah & Akhir \\
\hline 1 & /i/ & [i.duy?] 'hidup' & [li.hie] 'leher' & [la.br] 'kura-kura' \\
\hline 2 & /e/ & [e.ton] 'hitung' & [ᄁe.nc?] 'kecil' & [ce.ke] 'pelit' \\
\hline 3 & $/ \mathrm{a} /$ & [a.po?] 'napas' & [Ra.yI?] 'nyamuk' & [ki.ds] 'kiri' \\
\hline 4 & $/ \mathrm{u} /$ & [u.suyh] 'usus' & [ku.muah] 'kotor' & [i.du] 'cium' \\
\hline 5 & /o/ & [o.soh] 'gosok' & [lo.tean] 'loteng' & [ma.lo.yo] 'mual' \\
\hline
\end{tabular}

Tabel 8. Distribusi Fonem Diftong

\begin{tabular}{ccccc}
\hline No & Fonem & \multicolumn{3}{c}{ Distribusi Fonem Diftong } \\
\cline { 3 - 5 } & & Awal & Tengah & \multicolumn{1}{c}{ Akhir } \\
\hline 1 & /ia/ & - & [la.diay] 'golok' & [kam.bie] 'kelapa' \\
2 & /uy/ & - & [pa.tuyh] 'petir' & - \\
3 & /ua/ & - & [du.kuah] 'kalung' & [ku.hue] 'batuk' \\
4 & /ay/ & - & [a.kay?] 'Minggu' & [ba.lay] 'pasar' \\
5 & /aw/ & {$[\mathbf{a w}]$} & [Ra.baw?] 'rebab' & [la.paw] 'kedai' \\
6 & /ea/ & - & {$[$ lo.teay] 'loteng' } & - \\
7 & /oy/ & {$[\mathbf{o y}]$} & - & - \\
\hline
\end{tabular}

\section{Tabel 9. Distribusi Fonem Konsonan}

\begin{tabular}{|c|c|c|c|c|}
\hline \multirow[t]{2}{*}{ No } & \multirow[t]{2}{*}{ Fonem } & \multicolumn{3}{|c|}{ Distribusi Fonem Konsonan } \\
\hline & & Awal & Tengah & Akhir \\
\hline 1 & $/ \mathrm{p} /$ & [pa.wuy?] 'perut' & [ci.puy?] 'siput' & - \\
\hline 2 & $/ \mathrm{b} /$ & [bi.bie] 'bibir' & [lim.be?] 'limbat' & - \\
\hline 3 & $/ \mathrm{m} /$ & [mon.cuan] 'mulut' & [ji.ra.mi] 'jerami’ & [a.nam] 'enam' \\
\hline 4 & $/ \mathrm{t} /$ & [ta.kuy?] 'takut' & [li.ta?] 'lapar' & - \\
\hline 5 & $/ \mathrm{d} /$ & {$[$ da. $y \Lambda]$ 'dengar' } & [i.du] 'cium' & - \\
\hline 6 & $/ \mathrm{n} /$ & [na.nay] 'rayap' & [ne.nc?] 'kecil' & [sa.kın] 'pisau' \\
\hline 7 & $/ 1 /$ & [lu.tuan] 'lutut' & [ka.1ع?] 'getir' & [ka.re.kel] 'kerikil' \\
\hline 8 & $/ \mathrm{R} /$ & [Ra.ba?] 'awan' & [ci.ri?] 'tai' & - \\
\hline 9 & /s/ & [su.nuy?] 'kumis' & [mu.sa.jir] 'mesjid' & - \\
\hline 10 & $/ \mathrm{c} /$ & [ce.ga?] 'sembuh' & [man.cı?] 'tikus' & - \\
\hline 11 & $/ \mathrm{j} /$ & [jon.kon] 'peniti' & [ma.j $\Lambda]$ 'tumpul' & - \\
\hline 12 & $/ \mathrm{n} /$ & [ni.ru] 'niru' & [i.no] 'dia' & - \\
\hline 13 & $/ \mathrm{k} /$ & [ku.dua?] 'tengkuk' & [tun.kع?] 'tongkat' & [cin.kua?] 'bengkok' \\
\hline 14 & $/ g /$ & [ga.lo?] 'gelap' & [on.gch] 'burung' & - \\
\hline 15 & $/ \mathrm{y} /$ & [nv.yv.lay] 'pondok kayu' & [pon.kay] 'lempar' & [be.ran] 'marah' \\
\hline 16 & $/ \mathrm{h} /$ & - & [se.hay?] 'sehat' & [ta.buah] 'beduk' \\
\hline 17 & /w/ & [wa.li nu.ga.RI] 'kepala nagari' & [sa.ra.wı] 'celana' & - \\
\hline 18 & $/ \mathrm{y} /$ & [ya.yaw] 'palanca/rasuak' & [sa.na.yan] 'Senin' & - \\
\hline
\end{tabular}

\section{DAFTAR PUSTAKA}

Almos, R. (2012). Fonologi Bahasa Minangkabau: Kajian Transformasi Generatif. Wacana Etnik, 3(2). http://dx.doi.org/10.25077/we.v3.i2.33

Alwasilah, A. C. (2011). Linguistik Suatu Pengantar. Bandung: Angkasa.

Ayub, A., Husin, N., Muhardi, Usman, A. H., \& Yasin, A. (1993). Tata Bahasa

Minangkabau. Jakarta: Departemen Pendidikan dan Kebudayaan.

Chaer, A. (2013). Fonologi Bahasa Indonesia. Jakarta: Rineka Cipta.

Kridalaksana, H. (2013). Kamus Linguistik. Jakarta: Gramedia Pustaka Utama. 
Krulikowska, Ż., Nadra, N., \& Yusdi, M. (2020). Phonological Sketch of Malay Jambi Language of Sarolangun, Indonesia. Jurnal Arbitrer, 7(2), 173. https://doi.org/10.25077/ar.7.2.173-181.2020

Lia, E. A., Mulawarman, W. G., \& Hefni, A. (2018). Pronomina Persona dalam Bahasa Dayak Benuaq di Kecamatan Muara Lawa Kabupaten Kutai Barat. Diglosia: Jurnal Kajian Bahasa, Sastra, dan Pengajarannya, 1(1), 19-28. https://doi.org/10.30872/diglosia.v1i1.6

Muslich, M. (2013). Fonologi Bahasa Indonesia: Tinjauan Deskriptif Sistem Bunyi Bahasa Indonesia. Jakarta: PT Bumi Aksara.

Nadra, \& Reniwati. (2009). Dialektologi Teori dan Metode. Yogyakarta: Elmatera Publishing.

O'Grady, W., Archibald, J., Aronoff, M., \& Rees-Miller, J. (2017). Contemporary Linguistic. Boston: Macmillan Learning.

Rahmadani, Agustina, \& Amir. (2013). Perbedaan Fonetik Bahasa Minangkabau di Kenagarian Sinuruik dan Kajai Kecamatan Talamau Kabupaten Pasaman Barat. Jurnal Pendidikan Bahasa dan Sastra Indonesia, 1(2), 528-534. https://doi.org/10.24036/1369-019883

Rahman, F., Yandri, \& Gani, M. H. (2019). Variasi Bunyi Bahasa Kerinci Isolek Rawang. Krinok: Jurnal Linguistik Budaya, 4(1). https://ojs.umbbungo.ac.id/index.php/Krinok/article/view/336

Roach, P. (2012). English Phonetics and Phonology. Cambridge: Cambridge University Press.

Siminto. (2013). Pengantar Linguistik. Semarang: Penerbit Cipta Prima Nusantara. 